\title{
DA FÔRMA ÀS FORMAS: METRO, RITMO E TRADUÇÃO DO HEXÂMETRO
}

\author{
Robert de Brose* \\ Universidade Federal do Ceará
}

\begin{abstract}
Resumo: No presente artigo, pretendo discutir as possibilidades rítmicas do hexâmetro grego, demonstrando como esse metro, erroneamente reduzido a forma $5 \mathrm{da}+\mathrm{sp}$, reflete, na verdade, a articulação de vários cola métricos oriundos de diferentes tradições poéticas que se adequaram à fraseologia da poesia épica. Irei argumentar que as articulações rítmicas do hexâmetro são responsáveis por criar significados não triviais que precisam ser ressaltados na tradução, pois são parte integrante na construção do significado poético. Por fim, irei mostrar, por meio de três exemplos, como uma tradução que atente para a natureza polirrítmica do hexâmetro poderia ser levada a cabo.
\end{abstract}

Palavras-chave: Hexâmetro. Tradução do Hexâmetro. Métrica. Ritmo. Tradução Poética.

\footnotetext{
* Bacharel em Língua e Literatura Grega, Mestre e Doutor com "Distinção e Louvor" em Letras Clássicas pela Universidade de São Paulo. É membro permanente do Programa de Pós-graduação em Estudos da Tradução (POET) da Universidade Federal do Ceará e líder do Grupo de Pesquisa no CNPq "Tradução e Recepção dos Clássicos". Organizador do selo "Ecos" de tradução para a Editora Substânsia. Atualmente, dedica-se à tradução da obra completa de Píndaro, cujo projeto foi contemplado com o Edital Universal MCTI/CNPQ 2014. É Professor Adjunto de Letras Clássicas da Universidade Federal do Ceará. Fortaleza, Ceará, Brasil. Email: robert.de.brose@ufc.br
} 


\title{
FROM MOLD TO FORMS: METER, RHYTHM AND THE TRANSLATION OF THE HEXAMETER
}

\begin{abstract}
In this article I shall discuss the rhythmical possibilities of the Greek hexameter, showing how this particular meter, sometimes mistakenly equated with the form $5 \mathrm{da}+\mathrm{sp}$, is, in fact, the result of a confluence of metrical cola from different poetical traditions articulated by the phraseology of epic poetry. I shall argue that the rhythmical patterns of the hexameter are responsible for eliciting non-trivial connotations that need to be made explicit in the translation because they are an integral part for construing poetical meaning. Finally, I shall try to demonstrate, by means of three practical examples, how a translation that is aware of these rhythmical articulations might be possible.
\end{abstract}

Keywords: Hexameter. Translation of the Hexameter. Greek Meter. Poetic rhythm. Poetic translation.

Vai por cinquenta anos

Que lhes dei a norma:

Reduzi sem danos

A fôrmas a forma.

M. Bandeira, Os sapos.

\section{Introdução ${ }^{1}$}

A poesia grega do período arcaico $^{2}$ era indissociável de sua expressão musical e, ao menos no que tange à sua concepção ${ }^{3}$, de natureza eminentemente oral, orientada para a performance e, ademais, pública ${ }^{4}$. É muito importante que se ressalte tais características logo no início deste artigo justamente porque, muito embora reconhecidas pelos especialistas, raramente se presume que as mesmas possam ter alguma relevância em discussões acerca da tradução desses textos. Parece-me, todavia, que tais particularidades da poesia grega, justamente por diferenciá-la de maneira tão fundamental de nossa própria poesia, deveriam enquadrar toda e qualquer discussão desses textos, que, recebidos na modernidade por meio da escrita, são, na verdade, o registro entextualizado ${ }^{5}$ 
de canções compostas com o objetivo de ser executadas para uma audiência e com uma ocasião e propósito definidos.

Dessa forma, se por um lado a poesia grega é normalmente conceitualizada e problematizada na modernidade a partir do domínio ${ }^{6}$ daquilo a que chamamos de "literatura", caracterizada pela centralidade dada à palavra escrita, por outro lado, no período arcaico, ela se definia precipuamente a partir da dimensão da palavra falada ou, mais bem dizendo neste caso, cantada, e, portanto, caracterizarse-ia com mais precisão como uma "oratura"7. Isso porque, até a segunda metade do séc. IV, se não até mais tarde, as comunidades gregas ainda viviam, para todos os fins práticos, em uma cultura eminentemente oral $^{8}$. Dentro dessa cultura, o arcabouço das artes verbais recebia o nome mais esquemático de mousiké $\bar{e}^{9}$, isto é, a "arte das Musas", palavra que, com o advento da escrita, especializou-se, na maioria das línguas modernas, para se restringir apenas à música propriamente dita, que pode ser independente da palavra, mas que, então, subsumia: o conteúdo verbal (léksis; poiésis); a música e o canto (mélos, aōidé); e a dança (molpé, khoreía) ${ }^{10}$, todos indissociavelmente articulados numa mesma práxis poética.

Devido à sua natureza musical e performática, a poesia grega recorria a uma série de artifícios acústicos e visuais ${ }^{11}$, de caráter supralexical, na criação e explicitação de significados poéticos. Infelizmente, a maior parte dessas duas dimensões perdeu-se na transmissão do texto, já que os gregos nunca se preocuparam em preservar a notação musical da melodia de suas canções, e não se sabe de qualquer tipo de notação coreográfica. A língua grega, no entanto, devido à sua própria natureza, era capaz de codificar o metro das composições poéticas em sua estrutura fonética, que, em grande medida foi preservada na escrita. Graças a isso, hoje podemos, ao menos, conhecer com precisão os metros dos poemas estíquicos $^{12}$, como o hexâmetro, o dístico elegíaco, os trímetros e tetrâmetros, os epodos etc., e, por meio da escansão métrica dos versos, tentar recuperar seu ritmo musical, o qual, segundo irei argumentar, é um elemento capital para a compreensão da mensagem poética do texto. 
Voltando, no entanto, ao ponto inicial, e pressupondo-se que o texto dos poemas gregos seja uma forma de discurso oral preservado pela escrita, parece-me estar claro a importância de buscarmos uma abordagem tradutória que conceda uma ênfase maior aos aspectos privilegiados em uma obra vocal, entre os quais, o ritmo. Basta pensarmos, por exemplo que, para Paul Zumthor ${ }^{13}$, na poesia oral, "o ritmo é sentido, intraduzível em língua por outros meios", algo que os poetas, evidentemente, sabem de maneira instintiva, mesmo aqueles que operam num literacia completa, como a que vivemos. Para Maiakowski ${ }^{14}$, por exemplo, o ritmo é magnetismo, a força e energia fundamental da poesia. Consequentemente, mais do que mero ornamento, ele tem um papel crucial na explicitação de conteúdos semânticos não-verbais que, na poesia, por visar o au-delà da linguagem, precisam a todo custo ser preservados em tradução. Isso, contudo, não é alcançável por meio da reprodução mecânica de esquemas métricos, porque metro e ritmo não se confundem completamente. Como já nos alertava Aristides Quintiliano ${ }^{15}$, a canção em sua totalidade é expressa pela combinação de três eixos: melodia, ritmo e dicção (léksis), dos quais o metro é uma característica da letra (léksis), ao passo que o ritmo, expresso pelo movimento do som e pelas alterações (páthē) que lhe são impostas pelo executante, emerge da dança. Pode-se concluir, portanto, que o ritmo é conceitualizado, na prática musical grega, a partir dos movimentos da voz e do corpo na tridimensionalidade do espaçotempo ${ }^{16}$, e que aqueles se projetam sobre a letra, mas apenas como sombra, na forma do metro.

Dessa forma, na tradução da oratura grega arcaica, é preciso pensar em estratégias para se reconstruir o ritmo, isto é, a atualização do movimento, que é contínuo e sempre mutável, mais do que o metro, que determina apenas a equação e as leis desse movimento. Ademais, uma vez que o metro pertence à dimensão da léksis, e uma vez que o grego e o português têm lékseis diferentes, e em muitos pontos incompatíveis, é forçoso admitir que seus sistemas métricos não podem ser coincidentes. De fato, ao passo que o sistema de metrificação grego é morônico, isto é, baseado na du- 
ração da sílaba, que é uma característica fonêmica naquela língua, o do português é tônico, vale dizer, baseia-se na alternância entre sílabas fortes e fracas, já que em nossa língua a quantidade silábica, ainda que presente, não tem papel relevante na formação de pares mínimos contrastivos, e o contraste, como sabemos, é a essência mesma do ritmo. Além do mais, a versificação nas línguas neolatinas tende a seguir esquemas métricos rígidos, formados, como dissemos, por padrões de alternância do acento tônico em versos com um número fixo de sílabas ${ }^{17}$. Na poesia grega, pelo contrário, muito embora existissem esquemas isossilábicos, havia uma margem maior para variação, principalmente por meio da substituição de longas por breves e vice-versa, sobretudo na cabeça do verso, uma característica de formas mais antigas, indo-europeias. $\mathrm{O}$ hexâmetro, por exemplo, de que iremos tratar neste artigo, podia contar com um mínimo de 12 e um máximo de 16 sílabas, a partir das quais 32 formas métricas eram possíveis, as quais, por sua vez, poderiam ser articuladas de muitas maneiras para se produzir uma riqueza rítmica raramente salientada.

Em face, então, da natureza da poesia grega arcaica, da distinção estabelecida, já na Antiguidade, entre metro e ritmo e da importância desse último na criação de significado poético, sobretudo em formas orais de poesia, supor que, identificado o metro de um determinado poema, seja possível fixar uma determinada forma rítmica para aplicá-la indistintamente a toda tradução, é supor, automaticamente, que o sentido denotado por tal forma é adequado para todas as suas passagens, o que é um evidente absurdo: o ligeiro trote de um verso holodátilo seria totalmente inadequado a um funeral ou a uma cena de libação, assim como um verso holospondaico ${ }^{18}$ o seria para uma cena de combate. Neste artigo, portanto, tentarei demonstrar que o decalque métrico das formas originais não é a melhor abordagem para a tradução da poesia grega arcaica. $\mathrm{Na}$ verdade, parece me que a reprodução mecânica de esquemas métricos do grego para o português, muitas vezes tentando-se inclusive fazer coincidir sílaba longa com sílaba tônica, denuncia tanto uma certa desatenção à capacidade de elementos não-verbais de 
produzirem significado, o que é típico da mente quirógrafa, quanto um certo desprezo por aquelas características do poema que não estão sob o domínio da escritura e não contribuem para o desenho gráfico do texto na página, ou que, de outra forma, o desestabilizariam. No caso do hexâmetro, como veremos, essa desestabilização estaria representada na possibilidade de partir graficamente o verso homérico para melhor explicitar a sua estrutura rítmica, o que não deve ser visto como uma heresia.

A filologia clássica, que surgiu com a necessidade de se editar os textos dos poetas à medida que esses eram coletados em bibliotecas na Antiguidade tardia, como aquela de Alexandria, no séc. III a.C., relegou o estudo da métrica a um mero expediente editorial, a uma ferramenta auxiliar no estabelecimento do melhor texto de diferentes versões. Para o filólogo, que, com declínio no ensino das línguas clássicas, muitas vezes é o único tradutor disponível, o ritmo de um poema normalmente reduz-se a uma mera sequência de sinais tipográficos da forma - ou $\checkmark$, cuja dimensão musical ou performática é de somenos importância ${ }^{19}$. Não havia mesmo, até pouco tempo, um interesse em se recuperar essa música - ou qualquer música ${ }^{20}$ - no âmbito dessa disciplina, onde a métrica grega, mais do que servir para nos reconectarmos à mousike arcaica, foi reduzida a uma mera técnica acessória da crítica textual e a uma ferramenta que, embora, útil revela-se desagradável, não raro inconveniente e obscura, com a qual os editores têm de lidar no estabelecimento de seus textos.

Na tentativa de romper com essa ênfase dada ao desenho gráfico, típico da estrutura modal da literatura ${ }^{21}$ - e que tende à esquematização excessiva e à redução das formas a uma única fôrma na tradução -, mas, ao contrário, procurando salientar sua dimensão vocal, que reside no tempo da performance, e, portanto, manifestase no ritmo da voz, em canto ou recitação, mais do que no metro e no grafismo da página, irei, no que segue, analisar as poliformas subjacentes à matriz métrica prototípica do hexâmetro, tentando salientar toda a sofisticação, riqueza e complexa história evolutiva que ainda se faz sentir no texto de poemas fundamentais para a nos- 
sa cultura, como a Ilíada, a Odisseia e os poemas hesiódicos. Irei explorar, sobretudo, a articulação interna do hexâmetro e como ela age para expressar ou salientar significados, sem a presunção de que o tema possa ser esgotado por essa pequena análise, há muito trabalho ainda, nesse e em outros níveis, a ser feito antes que possamos compreender todas as possibilidades rítmicas desse verso e as funções que lhe foram dadas pelos diferentes gêneros que dele se utilizaram. Ainda, e seguindo o conselho de Schlegel ${ }^{22}$, irei propor uma maneira de ressaltar, na tradução, essa articulação rítmica e os significos que nelas vejo. Estou ciente de que este não é o único caminho possível e, portanto, os dois exercícios de tradução ao final desse artigo anseiam por ser mais propositivos que prescritivos.

\section{O hexâmetro grego}

O hexâmetro grego é tido normalmente como o metro mais simples em todo o rico inventário de metros gregos. De fato, qualquer um com um conhecimento básico do alfabeto e da prosódia daquela língua pode aprender a escandir esse verso em menos de cinco minutos. Essa aparente simplicidade é a razão pela qual quase todos os tratados de métrica modernos se iniciam por essa forma ${ }^{23}$, uma decisão, contudo, infeliz e que reflete, ademais, uma compreensão e uma recepção inadequada do verso na modernidade, porque nem do ponto de vista rítmico o hexâmetro é simples nem, diacronicamente, ele pode ser tido como uma protoforma, algo já reconhecido na própria Antiguidade.

De fato, para Aristóteles, o hexâmetro, em contraposição ao jambo, era um metro solene (semnós) e o mais desprovido dos ritmos da fala cotidiana ${ }^{24}$; o que faz sentido, se pensarmos que ele se desenvolveu para preservar narrativas que tampouco estão relacionadas com a vida, mas com as histórias maravilhosas de deuses e heróis. Dessa forma, também por codificar um discurso de autoridade - mítico, didático, filosófico etc. -, o hexâmetro evoluiu para acomodar uma dicção especialmente estilizada, o que 
o tornava, nas palavras daquele mesmo filósofo, "o mais pomposo e pesado dos metros, razão pela qual aceita, mais que todos os outros, palavras raras e metáforas, pois a imitação narrativa é a mais extravagante de todas" 25 . Antes, no entanto, de podermos apreciar toda essa sofisticação, é preciso que entendamos sua forma mais prototípica, isto é, o andamento rítmico tido como o melhor representante do metro em um conjunto de variações possíveis.

Tradicionalmente, essa forma é definida como um verso formado por cinco pés do tipo - $\backsim$, chamado dátilo, arrematados por um sexto do tipo - - - , que recebe o nome de espondeu ${ }^{26}$. Daí resultam as seis (hexa) medidas (metra) que dão nome ao verso com a seguinte configuração $0^{27}$ :

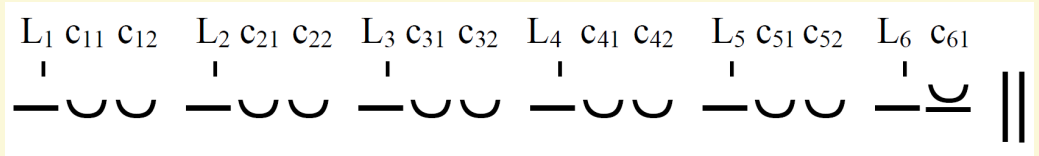

Essa forma do hexâmetro, que recebe o nome de (verso) "holodátilo", i.e., composto inteiramente por dátilos, não é nem a única forma possível, nem a mais frequente, muito embora possamos considerá-la, como dissemos, a matriz prototípica geradora de outras formas. Na verdade, o verso holodátilo aparece em apenas $20 \%$ de todos os versos da Ilíada e $29 \%$ dos da Odisseia; isto por-

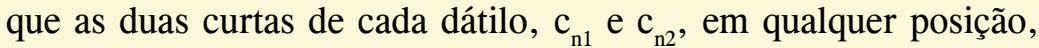
podem ser substituídas ${ }^{28}$ por uma única longa, o que expandiria o nosso esquema de possibilidades para

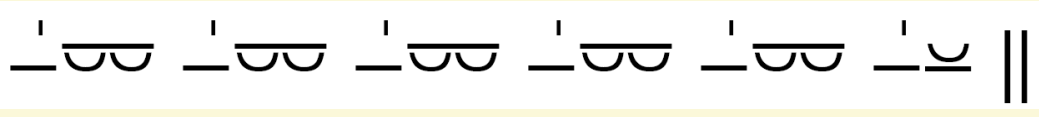

Essa plasticidade do metro permitia ao aedo, se assim quisesse, preencher todas as posições métricas unicamente com espondeus, produzindo o assim chamado verso holospondaico, que, muito em- 
bora apareça em seis ocasiões em Homero e em uma no Hino Homérico a Apolo, constitui-se uma verdadeira exceção ${ }^{29}$, sendo usado com parcimônia para produzir um efeito específico. A maior parte do corpus hexamétrico (70-77\%) apresenta, em média, apenas um ou dois espondeus por verso, em diferentes distribuições por posição ${ }^{30}$, o que assegura uma variedade ótima de combinações rítmicas, dando origem a 32 formas possíveis e atestadas de hexâmetros $^{31}$.

Para além da superfície dessa matriz métrica explicitada acima, escondem-se possibilidades rítmicas determinadas, em primeiro lugar, pelo valor da razão entre a duração de uma longa em posição marcada e das duas breves que lhe seguem, e, também, pelo valor da longa final. Em segundo lugar, é preciso levar em conta o efeito, sobre o ritmo, da presença/ausência de pausas internas no verso, bem como de suas diferentes colocações. Todos, elementos "supranotacionais" normalmente não indicados em edições modernas, exceto pelo uso, aqui e acolá, de vírgulas ${ }^{32}$. Irei abordar essas duas questões no que se segue.

\section{As multiformas do hexâmetro}

\subsection{O problema das relações temporais}

Na medida em que o hexâmetro é composto por cinco pés da forma $\mathcal{L} \sim$, poderíamos pensar que a contração das duas breves do dátilo resultaria em uma longa com a mesma quantidade, e, de fato, teóricos como Heféstião aparentemente tomavam essa equivalência como certa, talvez em virtude de seu objetivo prático, que era, principalmente, o de reconhecer metros e poder detectar anomalias em textos transmitidos via escrita. Do ponto de vista da performance, contudo, há evidências convincentes para pensarmos que essa questão não era assim tão simples.

Dioniso de Halicarnasso, por exemplo, falando especificamente do hexâmetro, explica que "de fato, os ritmistas dizem que a longa 
desse pé [i.e., o dátilo] é mais curta que a longa perfeita ${ }^{33}$, e, não sendo capazes de dizer em que proporção, chamam-na de irracional (álogon)" ${ }^{34}$. Aqui, o termo álogos, ou irracional, é usado no seu sentido técnico de "cuja relação de tempos não pode ser expressa por uma fração (lógos)" 35 , o que significa que o tempo da tese $\left(\mathrm{t}_{\theta}\right)$ dividido pelo da arse $\left(\mathrm{t}_{\alpha}\right)$ era menor que 1 por um valor $x$ que os gregos não conseguiam quantificar por desconhecerem decimais, muito embora o descompasso entre tese e arse lhes fosse evidente ${ }^{36}$.

Um indício dessa inequação entre a tese e a arse do dátilo pode estar por trás do fato de que esse metro, sobretudo em sua forma recitada $^{37}$, não admite a resolução da longa em duas curtas, ao contrário de sua forma antitética, o anapesto, $\sim \sim{ }^{38}$, em que a longa final, por ter a mesma duração da soma das duas breves iniciais ${ }^{39}$, abre espaço para três possibilidades rítmicas impossíveis para o dátilo: (a) resolver a sua longa em duas breves, dando origem ao que os antigos metricistas chamavam de proceleusmático, u ¿́v; (b) contrair as duas breves iniciais em uma longa, dando origem a um anapesto a maiore, - -v' , que difere do dátilo pela posição da tese e, como explicamos, pela razão entre seus tempos; ou, ainda, (c) contrair as quatro breves em duas longas, $-\perp^{40}$. No caso do anapesto, isto só é possível porque a razão (lógos) entre o $\mathrm{t}_{\theta} \mathrm{e} o$ da $\mathrm{t}_{\alpha}$ existe e é, para todos os fins práticos, sentida como sendo igual a 1.

No que diz respeito ao alongamento da sílaba final do hexâmetro, Heféstião e Aristides Quintiliano parecem fazer uma distinção entre versos acataléticos, ou seja, que terminariam com quatro tempos na posição 6 , e versos cataléticos ${ }^{41}$, que terminariam com três tempos naquela posição. Do ponto de vista puramente métrico, um verso acatalético encerrar-se-ia com um espondeu, contando, portanto, quatro tempos, dois para tese e dois para a arse, ao passo que um verso catalético fecharia com um crético $(-\smile)$, contando três tempos, dois para a tese e um para a arse. Entretanto, do ponto de vista rítmico, isto é, da realização do metro na performance, esses mesmos tratados são unânimes em reconhecer que qualquer sílaba em final de verso torna-se longa devido à pausa imposta ao final de uma linha, e que, ademais, esse alongamento independeria 
da duração natural da sílaba, de forma que mesmo um crético, ¿-৬, teria sua sílaba breve final alongada, resultando em - - (oriundo de $\left.-\cup_{\wedge}^{42}\right)$ e, por essa razão, essa última sílaba era chamada de adiáphoron, ou seja, "indiferente".

O grande problema aqui está justamente em determinar o valor temporal da segunda longa do espondeu final se postularmos, como me parece plausível, que seu valor deveria ser diferente da longa marcada: seria ela mais longa que a longa comum, como ocorre com as longas originárias da contração de duas curtas? Ou, ao contrário, mais breve? E, se uma ou outra, em qual proporção? $\mathrm{Na}$ prática, todas essas incertezas deveriam ser resolvidas pela performance e pelo contexto específico de cada passagem, mais do que por uma adesão incondicional a valores métricos completamente abstratos, e isso se torna evidente se pensarmos nos casos de versos em acavalamento, sobretudo os do tipo necessário ou sintático ${ }^{43}$ : uma pausa menor ajudaria a resolver o sentido do verso mais rapidamente; uma pausa maior, no entanto, serviria a um grande efeito dramático por dilatar ao máximo o suspense na audiência para em seguida recompensá-lo com a sua resolução. Todas essas possibilidades poderiam, dessa forma, ser manipuladas de acordo com a ocasião e a vontade do aedo, com vistas a maximizar a atenção da audiência. Todas elas, da mesma forma, podem e devem ser levadas em conta na hora da tradução.

\subsection{Pausas internas}

Um outro aspecto não menos controverso, mas que contribui decisivamente para a diversificação rítmica do verso épico, são suas pausas, que podem ser induzidas por dois tipos básicos de interrupção na sinafia interna das sílabas: final-de-palavra (coincidindo, ou não, com uma pausa semântica, com o fim de um pé en $^{44}$ ou ambos) e hiato. Do ponto de vista da performance, a pausa, além de provavelmente ter sido usada como um recurso prosódico, permitindo ao aedo respirar antes de atacar a segunda parte do verso, também 
o divide em duas metades variavelmente desiguais e, desta maneira, evita sua desagregação, que poderia advir de um corte em alguma posição fixa a suceder-se linha após linha ${ }^{45}$. Reforça essa hipótese o fato de que parece haver uma cautela maior no intervalo entre $c_{32}$ e $\mathrm{L}_{4}$, onde final-de-palavra ou hiato são constantemente evitados a fim de não dividir a linha em dois hemistíquios de um trímetro cada. A posição onde há essa tendência, ou até mesmo a proibição, em se evitar fim-de-palavra ou hiato chama-se "ponte" ${ }^{46}$. Nos pés trissílabos, a existência de pontes indica que fim-de-palavra não pode acontecer na primeira curta de um pé; no caso dos dissílabos, isto é, quando há a contração das duas curtas do dátilo em uma longa, a ponte adiantar-se-á uma posição, aparecendo após a segunda longa. No hexâmetro, além de se evitar uma cesura medial, nota-se também uma tendência para que fim-de-palavra não recaia entre $c_{21} \mathrm{e}_{22}$, bem

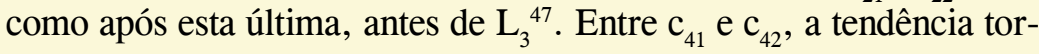
na-se uma proibição, a assim chamada "Ponte de Hermann".

Já na Antiguidade, reconheciam-se três pausas principais: a pentemímere, logo após as posições $\mathrm{L}_{3}$ e $\mathrm{c}_{31}$, chamadas respectivamente de cesura masculina (M) e feminina (F); a heptemímere ${ }^{48}(\mathrm{H})$, após $\mathrm{L}_{4}$; e a diérese bucólica (B) ${ }^{49}$, após $\mathrm{c}_{42}$. Fränkel, em um estudo importante ${ }^{50}$, propôs que os dois hemistíquios separados por $\mathrm{M} \mathrm{ou}$ F, por sua vez, subdividir-se-iam em mais duas partes e que, além do mais, esses cortes seriam motivados pela semântica do verso, daí tê-las chamado de "pausa-semântica" (Sinneseinschnitte) ${ }^{51}$. A distribuição das pausas possíveis em um verso daria origem ao seguinte quadricolon com três áreas principais (A, B, C e coda) onde pausas-semânticas poderiam ocorrer:

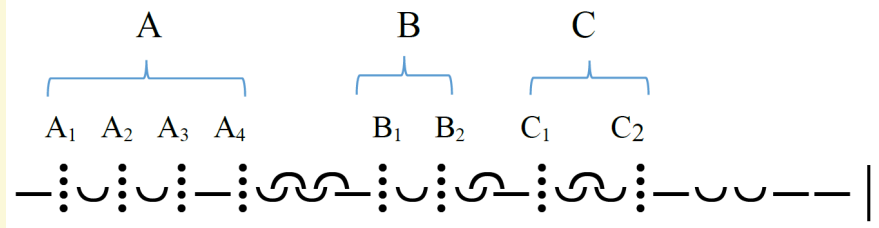


onde: $\mathrm{B}_{1}=\mathrm{M} ; \mathrm{B}_{2}=\mathrm{F} ; \mathrm{C}_{1}=\mathrm{H} ; \mathrm{C}_{2}=\mathrm{B}$. Note como o verso evita qualquer tipo de contração ou pausa em sua coda

Dentro da seção A, as pausas $\mathrm{A}_{1}$ e $\mathrm{A}_{2}$ são muito incomuns, como podemos ver no esquema abaixo, onde procurei reunir sinopticamente as posições reconhecidas como propensas a apresentar fimde-palavra, e incluí, ainda, a frequência (em porcentagem) para cada uma delas ${ }^{52}$ :

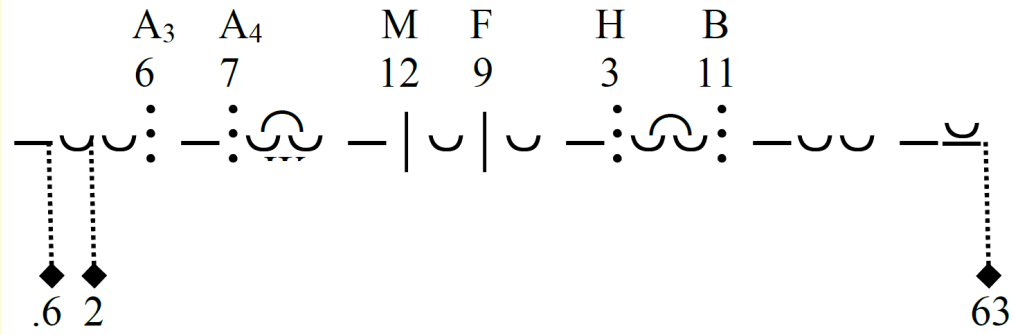

Muito embora a análise do hexâmetro a partir de um quadricolon ainda goze de muito prestígio e seja, de fato, bastante útil na análise do hexâmetro, Kirk ${ }^{53}$, por exemplo, ressalta que, ao contrário do que Fränkel ${ }^{54}$ poderia pensar, as pausas não existem para ser preenchidas pelo conteúdo, mas, ao contrário, elas devem refletir um modo de articular a linguagem tradicional da poesia hexamétrica.

A utilidade e a limitação desse tipo de análise fica clara quando examinamos versos como os seguintes:

1. Il. 1.29

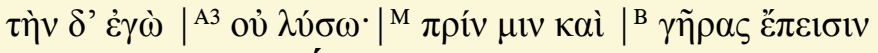
tēn d'egō | ou lǘsō | prín min kaì | gểras épeisin

$-\smile \cup|---|---|-\cup \cup--| \mid$

ela eu não libertarei; não antes que lhe sobrevenha a velhice 
2. Il. 3.398

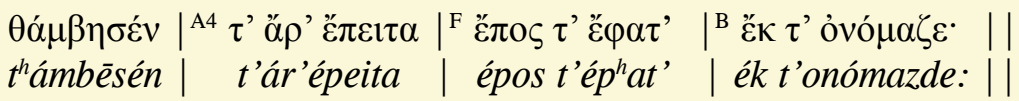

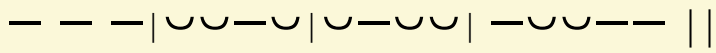

pasmou; mas então, dirigindo-lhe a voz, chamou-o e disse:

Obviamente, a cesura central - $\mathrm{M}$, no primeiro caso, e $\mathrm{F}$, no segundo - continua sendo a mais explícita (note o hiato no segundo exemplo), ao passo que as outras dependem de uma interpretação subjetiva ou rítmica da linha, provavelmente subordinada à performance. Dessa forma, se tormarmos a fala de Agamênão no primeiro verso, não seria improvável que o aedo preferisse dar um andamento lento e, portanto, maior ênfase a uma fala tão dura, consequentemente isolando cada colon do hexâmetro, sobretudo após prín min kaì, que anuncia a duração vitalícia da futura escravidão da filha de Crises: até que... a velhisse lhe alcance. Por outro lado, é bem mais difícil entender como, no segundo exemplo,

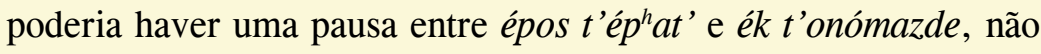
apenas devido à forte sinafia marcada pela elisão final de é $p^{h} a t^{\prime 55}$ mas sobretudo pela unidade formular e semântica das duas expressões, algo semelhante ao nosso (mais coloquial) "falou e disse".

É preciso salientar, ainda, que alguns versos parecem não apresentar qualquer tipo de cesura identificável ${ }^{56}$, ao passo que outros encaixam-se muito melhor numa estrutura tripartite que Kirk, ao explicitá-la pela primeira vez, chamou de "rising threefolder" e que eu traduzo aqui como "tríptico ascendente", cujo exemplo mais claro pode ser visto em 
3. Il. 2.173

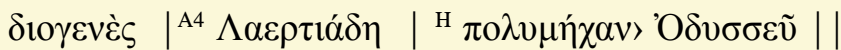

dīogenès | Laertiádē | polumē̄k $k^{h}$ an'Odussêิ ||

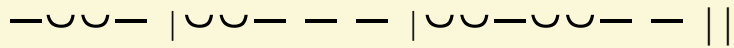

ó diva progênie, filho de Laertes, multimanhoso Odisseu!

onde não é possível dividir o verso nem após $\mathrm{L}_{3}(\mathrm{M})$ nem após $\mathrm{c}_{31}$ (F), já que essas duas pausas caem dentro de um única palavra, Laertiáde ( $\bullet---)$. Por outro lado, há uma forte pausa após $\mathrm{L}_{2}$ ( $\mathrm{A}_{4}$ no esquema de Fränkel), sobretudo em virtude do encontro de sibilante com líquida, e após $\mathrm{L}_{4}(\mathrm{H})$, as quais dividem o verso em três movimentos claramente ascendentes ${ }^{57}$ que dão nome a este perfil rítmico.

Kirk nota que o uso de trípticos ascendentes é reservado para momentos climáticos da narrativa, como no exemplo abaixo, em que Apolo chega à Troia para punir os gregos:

4. Il. 1.48

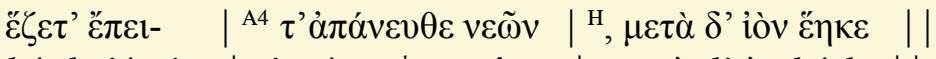
hézdet'épei- | t'apáneuthe neôn |, metà d'ìòn hééke ||

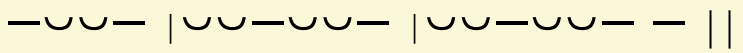

senta-se então, e à parte das naus, solta uma flecha.

Note como cada uma das ações é sublinhada por um colon com conteúdo semântico bem demarcado, quase como se tivéssemos três cenas de uma tomada cinematográfica, close-up, zoom out, 
tracking shot: senta-se/ longe das naus/ lança uma flecha ${ }^{58}$. Ainda que haja fim-de-palavra após $\mathrm{c}_{42}(\mathrm{~B})$, dificilmente poderia haver uma pausa neste ponto, já que a preposição, que aqui não tem valor adverbial, encontra-se em tmese (i.e., separada do verbo héeke, na forma da $3^{\mathrm{a}}$ p. do aor. sing. de hiémi), a que de fato pertence e com que forma uma unidade inseparável: methiémi.

Um outro aspecto, e até onde eu sei, jamais salietado pelos tradutores modernos acerca da estrutura do hexâmetro é que suas pausas internas revelam pontos de junção de cola empregados de maneira independente em outras formas poéticas, sobretudo na lírica. Dessa maneira, pode-se hipotetizar que uma estilização progressiva, aliada à evolução e à consequente estabilização de uma fraseologia épica, deve ter sido responsável por selecionar, a partir de inúmeras combinações iniciais, um subconjunto de possibilidades rítimicas que veio a compor a matriz prototípica do hexâmetro. Isso quer dizer que todo verso com ao menos uma pausa bem marcada (cesura ou diérese) poderá ser decomposto em dois cola rítmicos que cirscunscrevem unidades formulares, semânticas e/ou narrativas bem delimitadas que, por sua vez, contribuem de maneira não trivial para o sentido do verso ou da cena narrada, o que veremos a seguir.

\section{Ritmo como criador de significado}

O parentesco das formas gregas com outras tradições métricas indo-europeias foi notada pela primeira vez por Meillet e, a partir de seu estudo seminal ${ }^{59}$, muitos outros sucederam-se. O que se percebe, no entanto, é que, até hoje, essas descobertas da filologia tiveram pouco ou nenhum impacto na prática tradutória, que, como já disse, nunca procura ir além da fôrma métrica. O assunto, certamente, é complicado, mas, se devidamente fudamentado, pode abrir uma nova dimensão para a tradução e a apreciação da poesia grega antiga, como espero mostrar.

A abordagem que pretendo dar à análise de alguns exemplos da épica grega baseia-se principalmente no estudo de Nagy ${ }^{60}$ acerca 
da evolução diacrônica do hêxametro a partir de formas líricas, sobretudo de cunho dátilo-epitrítio e eólico. Não teríamos espaço para uma análise detalhada de seu complicado raciocínio, mas, resumidamente, para Nagy, é possível entender o hexâmetro como originando-se tanto a partir de um processo de junção de uma sequência métrica comum nos poemas lírico-épicos de Estesícoro, o prosodíaco, quanto a partir da expansão dactílica da forma catalética do glicônio, conhecida como ferecrácio.

O primeiro caso é mais simples de ser ilustrado. A configuração métrica do prosodíaco é $\times-\backsim v-\cup v-$. E seu dímetro normalmente toma a forma de $\wedge-\cup \cup-\cup \cup-\times-\cup \cup-\cup \cup-{ }^{61}$, onde $\times$ pode ser substituída por um longa, uma breve ou duas breves. Quando $\times$ é substituída por uma longa ou duas breves, o dímetro torna-se indistinguível do hexâmetro. Comparece estas duas passagens, uma recuperada de um papiro ${ }^{62}$ com versos de Estesícoro e, a outra, de um verso da Ilíada:

\section{Estesícoro,}

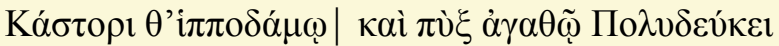
Kástori thippodámōi | kaì pýks agathōi Polydeýkei || a Cástor doma-cavalos | e ao bom de soco, Polideuces.

6. Il. 3.237,

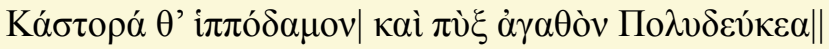
Kástora thippódamon | kaì pýks agat òn Polydeýkea || Cástor doma-cavalos $\mid$ e o bom de soco, Polideuces. ${ }^{63}$

ambos com a mesma forma métrica $-\cup v-\cup v-|--\cup v-\cup v--| \mid{ }^{64}$. Além do mais, como Nagy e outros já apontaram, tanto os datiloepitrítios de Estesícoro quanto os hexâmetros tendem a ter finalde-palavra em locais coincidentes. 
Já para o segundo caso, precisamos considerar que o glicônio, $\times \times-\backsim \cup-\cup-$, pode apresentar expansões internas em coriambos, $-\backsim \cup-$, ou dátilos, $-\cup \cup$, dando origem a formas como $\times \times=$

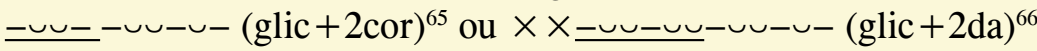
atestadas para os poetas eólicos. Quando o glicônio perde a sua última sílaba, ele recebe o nome de ferecrácio, $\times \times-\backsim \cup--$. Se, agora, esse ferecrácio for expandido por 3da, então teremos um verso

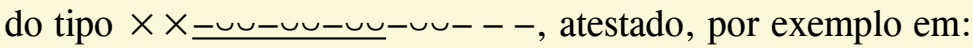

7. Alceu, fr. 368.1-2,

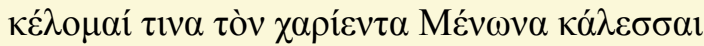

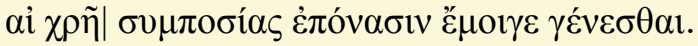
kélomaí tina tòn $k^{h}$ aríenta Ménōna kálessai ai $k^{h} r e ̂$ symposíās epónasin émoige génest ${ }^{h} a i$.

$--\mid-\cup \cup-\cup \cup-\cup \cup-\cup \cup--$

Peço a alguém chamar o gracioso Menão, se este simpósio deve me ser agradável.

Onde o segundo verso assume uma forma idêntica à de um hexâmetro com diérese em $\mathrm{A}_{2}$. Dependendo de onde houver final-de-palavra nos versos eólicos, podemos associá-los com diferentes formas do hexâmetro. Não se deve deduzir, no entanto, que, sincronicamente, essas formas fossem equivalentes, muito embora elas pudessem se influenciar. Elas representam, no entanto, diferentes estágios e caminhos na evolução das formas métricas gregas e nos ajudam a entender que os blocos de construção do hexâmetro de fato não são os seis pés nos quais se costuma dividir esse verso, mas sim cola determinados pela dicção épica ao longo de sua evolução ${ }^{67}$.

Estamos então agora preparados para analisar algumas passagens escolhidas de Homero, mostrando de que maneira essa dicção 
épica articula-se para criar significados a partir da matriz prototípica do hexâmetro vista anteriormente. Também, de que maneira esses significados podem ser explicitados em uma tradução para o português. Devido ao espaço exíguo deste artigo, farei uma análise métrica detalhada, utilizando os princípios discutidos até aqui, apenas do primeiro exemplo. Essa mesma análise deve ser subentendida para os exemplos subsequentes, onde apresentarei apenas as pausas relevantes para a tradução. Em nosso primeiro exemplo, então, que é

\section{Il. 23.210}

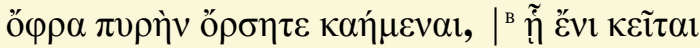

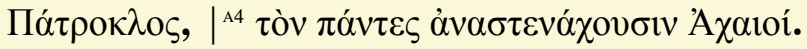

óphra pyrēn órsēte kaèmenai, | hêi éni keîtai

Pátroklos |, tòn pántes anastençak ${ }^{h}$ ousin $A k^{h}$ aioi

Para que levanteis uma pira a queimar. Onde jaz

Pátroclo, a que todos os aqueus dão queixumes.

vemos que o primeiro verso, que está dividido em dois cola separados pela cesura bucólica, pode ser interpretado ritmicamente ou como um tetrâmetro dactílico ${ }^{68}$ seguido de um adoneu ${ }^{69}$ ou, então, valendo-nos da análise de Nagy, podemos derivá-lo de um verso do tipo fer $+3 \mathrm{da}^{70}$ com resolução da segunda sílaba da base em duas breves e contração da segunda bíceps; isto é, uma evolução

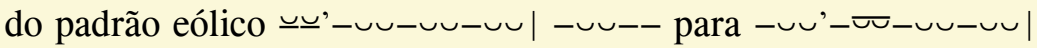

O segundo verso começa em acavalamento e tem, como é comum nesses casos, a cesura principal adiantada para a posição $\mathrm{A}_{4}$. Isso delimita e enfatiza o termo acavalado: - - - |- -৩৩-৩৩-৩৩--. Um tal padrão é encontrado nos glicônios com expansão dactílica, como, por exemplo, no segundo verso do exemplo 7 acima, clas- 
sificado por Heféstião, ademais, como um hexâmetro eólico dactílico catalético ${ }^{71}$. Fim-de-palavra também é comum nessa mesma posição nos glicônios com expansão coriâmbica ${ }^{72}$ que compunham todo o primeiro livro de canções de Safo e muitas das canções de

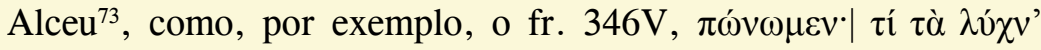

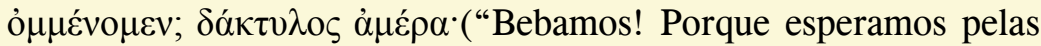
lamparinas? Resta apenas um dedo de dia!"), cujo esquema - -

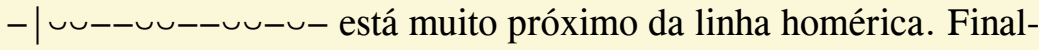
mente, talvez num estágio mais avançado de sua evolução, vemos essa mesma fraseologia rítmica nos dátilo-epitrítios de Estesíco-

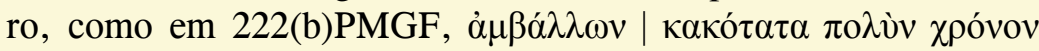
[, cujo esquema métrico é idêntico ao do exemplo homérico: - -

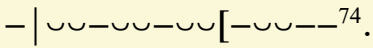

Dessa maneira, levando em consideração a articulação métrica do verso e a fraseologia épica, acredito que não se poderia tirar nenhuma vantagem, para o leitor de uma tradução, nem da reprodução mecânica da matriz $5 \mathrm{da}+\mathrm{sp}$, nem da insistência em traduzir um verso do original por uma única linha, a fim de simular, por um ou outro artifício, a aparência do hexâmetro. Ao contrário, uma grande parte da carga semântica, tão importante nessas passagens carregadas de emoção do livro XXIII, perder-se-ia. O que proponho, então, é que nos livremos das fôrmas impostas pela tradição literária e por uma rigidez infrutífera, e busquemos, na tradução, a ressonância rítmica que, mesmo não sendo (porque não poderá sê-lo nunca) idêntica ou equivalente ao original, direciona, por meio de uma outra estratégia, nossa atenção para os sentidos naquele aludidos. Para o exemplo 8, salientando as pausas assinaladas para o verso por meio da quebra de linha, eu proporia a seguinte tradução:

\author{
Para que levanteis uma pira a queimar. \\ onde jaz \\ Pátroclo, \\ a que todos aqueus dão queixumes ${ }^{75}$.
}


Abaixo repito o mesmo processo com mais alguns versos do mesmo canto, a fim de demonstrar outras articulações possíveis e a solução que proponho para preservá-las na tradução:

8.

Il. 23.217

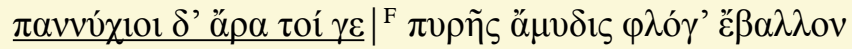

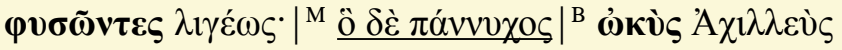

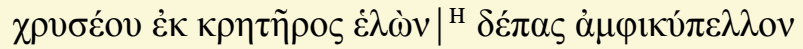

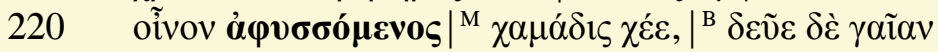

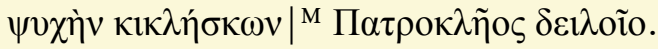

A noite inteira, então, eis como juntos $^{76}$ a chama da pira acenderam assoprando-a em silvos; noite adentro ei-lo também, o rápido Aquiles:

de uma cratera de ouro, tendo bialada uma taça tomado,

215 e o vinho exaurido,

deita-o ao chão

e molha a terra.

Pel'alma sempre

clamando

do pobre

Pátroclo.

Note o paralelismo entre "noite adentro [eles]" e "noite adentro [aquele]"; ainda, entre as duas cenas que se desenrolam simultaneamente, a ocorrência de uma forte cesura masculina no v. 2 . Depois dessa, a cesura bucólica não é obrigatória, devido à sinafia entre o sigma e a vogal seguinte de "Aquiles", mas ela tem uma função importantíssima, que é a de reintroduzir, no frame aberto pelo primeiro "noite adentro [eles]", a figura do herói principal, 
como se a primeira cena fosse um preview $^{77} \mathrm{e}$, a segunda, o zoom: “ele também estava lá: o rápido Aquiles". Com o foco estabelecido, a audiência pode-se concentrar no que Aquiles faz e, aqui outra vez, o contraste com o seu epíteto, ōkhýs, "rápido", destoa do lento crescente dos versos seguintes em que as oferendas fúnebres à Pátroclo são enquadradas em cenas muito bem delimitadas. Note que a antecipação da cratera de ouro faz com que a taça bialada surja, aos olhos da audiência, de dentro do frame daquela, além de criar um certo suspense, mantendo o foco da atenção. O terceiro verso está dividido em três frames que delimitam três ações distintas, mas a função mais importante dessas divisões é salientar a lentidão e o caráter doloroso da ação de prestar as exéquias ao querido amigo. Finalmente, a invocação à alma de Pátroclo é descrita em um raro verso holospondaico, com a cesura masculina a separar o objeto da ação, dando-lhe a máxima saliência possível.

Um outro exemplo, interessante, mas dessa vez da Odisseia, é o famoso canto das Sirenas, que, em vão, atentam Odisseu para que pare sua nau e ouça seus cantos, a fỉm de destruí-lo:

9. Od. 12.184

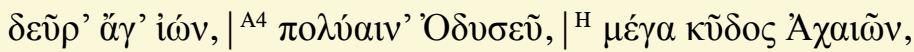

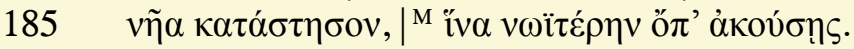

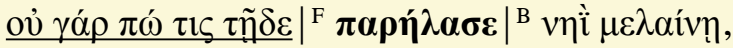

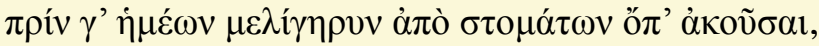

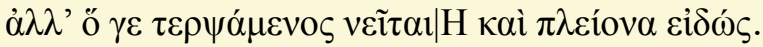

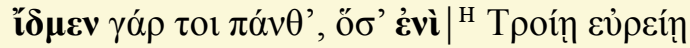

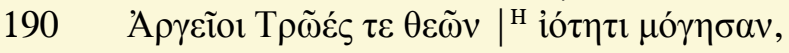

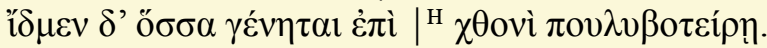

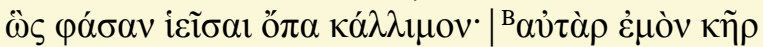

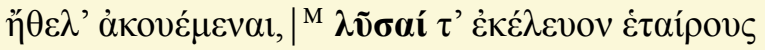

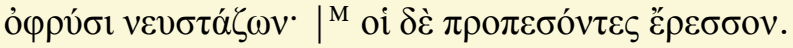

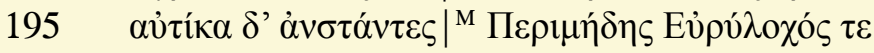

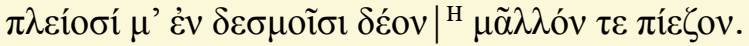

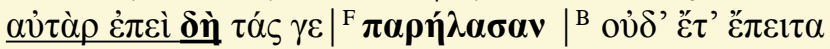




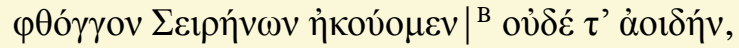

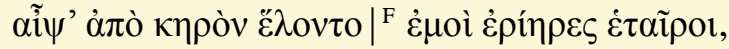

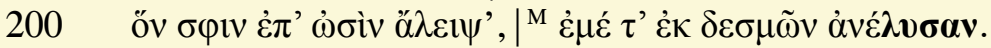

"Anda, acá vem

mui caviloso ${ }^{78}$ Odisseu

grande condão dos Aqueus!

185 Tua nave detém

para ouvir novíssimo um canto.

Pois nunca, ninguém, por aqui,

ao largo passou

em nave escura

antes ao menos de ouvir-nos da boca melífluo canto

Mas deleitando-se parte, $e$

mais sábio que outrora!

Sabemos pois tudo o que

na vasta Tróia

190 Argivos e troianos, dos deuses

pela vontade penaram.

Sabemos tudo o que sobre

a terra frutífera dá-se".

Assim disseram, lançando belíssima voz,

e o meu coração

quis escutar

soltar-me pedi aos amigos

franzindo o senho -

eles à frente remaram.

195 E de pronto tendo-se levantado

Perimedes, Euríloco,

com mais nós me ataram;

mais forte apertaram.

E depois que, sim, delas

ao largo passamos

e não mais

a voz das sirenas ouvimos

e nem sua canção 


\section{De seus ouvidos a cera tiraram}

meus fiéis companheiros,

200 que antes ali colocaram,

e dos liames então me soltaram.

Como o trecho é extenso, limitar-me-ei a fazer apenas algumas observações. Em primeiro lugar, há de se notar o tríptico ascendente do primeiro verso que, num crescendo, acumula elogios cada vez maiores sobre Odisseu. Em seguida, porém, o movimento lento do início do $v$. 186 até a primeira cesura $\left(-----\left.\cup\right|^{\mathrm{M}}\right)$ sublinha o inescapável destino que o esperaria, ao mesmo tempo em que confere um caráter sinistro ao fascinante canto das Sirenas. O $v$. 187, que descreve seu melodioso canto, flui sem ser interrompido por qualquer cesura, e a riqueza das líquidas o move numa onda encantatória, propelindo-nos à frente, atraindo-nos (e a sua nau) cada vez mais para dentro do canto. Odisseu não resiste, como Circe já previra, ao encanto. Sua luta para se soltar, contrabalanceada pelas ações dos companheiros para protegê-lo, estende-se pelos versos seguintes, em que ações em sentidos opostos são contrabalanceadas pela cesura masculina e feminina, enquanto a ênfase e os complementos localizam-se após a cesura pentemímere e a diérese bucólica. A perigosa passagem resolve-se numa bela estrutura em anel também articulada pelo ritmo: no início, as Sirenas haviam lhe assegurado que: "nunca, ninguém, por aqui, $\mid{ }^{\mathrm{F}}$ ao largo passou $\left.\right|^{\mathrm{B}}$ " e agora Odisseu, narrando, nos informa que "E depois que, sim, delas $\left.\right|^{\mathrm{F}}$ ao largo passamos $\left.\right|^{\mathrm{B}}$, , num perfeito exemplo paralelismo métrico entre as duas cenas. 


\section{Notas}

1. Gostaria de agradecer a Sandra Rocha e a Agatha Bacelar o convite para participar no V Seminário do Núcleo de Estudos Clássicos da UNB, em 2014, onde uma primeira versão desse artigo foi apresentada. Sou-lhes igualmente grato, e ao público lá presente, pelas perguntas e sugestões que ajudaram a melhorar o presente texto. Agradeço à UNB e ao NEC o financiamento das minhas despesas de viagem para a participação no referido evento. Uma segunda versão deste artigo, dessa vez com as propostas de tradução aqui incluídas, foi apresentada durante a Jornada Fórmula e Verso, promovido pelo GP-CNPq "Gêneros Poéticos na Grécia Arcaica", liderado por Christian Werner, e pelo GP-CNPq "Tradução e Recepção dos Clássicos", liderado por mim, na Universidade de São Paulo em 2015. Nessa ocasião, tive o privilégio de poder aproveitar as sugestões e as críticas do público, do próprio Christian e do companheiro de mesa, Marcelo Tápia, aos quais sou grato. Finalmente, agradeço à Universidade Federal do Ceará pelo financiamento de minhas despesas de viagem à Universidade de São Paulo naquela ocasião.

2. Por "poesia período arcaico", eu subentendo todo tipo de manifestação poética produzida entre Homero e Píndaro, ainda muito do que aqui se diz vale também para o período clássico, até a morte de Eurípides. Quando eu me referir a "poesia grega" sem qualquer qualificação, subentenda-se, portanto, que estou falando daquela do período arcaico.

3. Isto é, no diz respeito à estrutura do discurso, que, muito embora nos tenha chegado via escrita, revela traços de uma oralidade primária. Para uma distinção entre oralidade/literacia medial e conceitual em Homero, cf. Bakker (1997) a distinção foi fundamentada pela primeira vez por P. Koch e W. Oesterreicher no artigo "Sprache der Nähe - Sprache der Distanz: Mündlichkeit und Schriftlichkeit im Spannungsfeld von Sprachetheorie und Sprachgeschichte". Romanisches Jahrbuch, 36, pp. 15-43.

4. Acerca da cultura musical grega, uma boa introdução é o trabalho panorâmico de Gentili (1990). Sobre oralidade na Grécia arcaica e como ela implica em uma organização do discurso que é diversa daquela de uma literacia, cf. Havelock (1991; 1996), p. 11-27.

5. Segundo Bauman e Briggs (1990), pp.59-88, a entextualização é "o processo de tornar um discurso extraível, de transformar uma certa extensão de produção 
linguística em um unidade - um texto - que pode ser extraída de seu cenário interacional".

6. Palavras como domínio, esquema, frame, enquadrar, esquemático, marcado, não-marcado, metáfora conceitual etc. são sempre empregados na acepção técnica que a Linguística e a Poética Cognitivas lhes conferem. Para chamar a atenção do leitor para o vocabulário técnico dessas disciplinas, tais termos serão sempre grafados em itálico. Para uma referência rápida acerca do significado desses termos, quando o mesmo não for evidente a partir do contexto, o leitor pode consultar o excelente glossário de Evans (2007).

7. O termo "oratura" - a partir daqui, sem aspas - foi criado por Pio Zirimu que o teria cunhado em 1977, em conjunto com Austin Bukenya, em um artigo intitulado Oralcy as a Tool for African Development, lido na Festac de 1977 em Lagos (Thiong'o, 1998). Segundo Finnegan (1992:2003), p. 15, "it avoids the etymological problems of 'oral literature' and is also a positive term in its own right (the parallel to écriture) in the context of 'decolonising the mind"'.

8. Sobre isso, cf. especialmente Thomas $(1989 ; 1992)$.

9. Optei por utilizar a forma transliterada dos termos gregos sempre que possível. Nos exemplos práticos ao final do artigo, no entanto, por uma razão de espaço, isso não seria possível. Todos os exemplos, no entanto, podem ser ouvidos, lidos por mim no original, em soundcloud.com/robert_de_brose.

10. Brevemente, por léksis, um termo bastante polissêmico, eu entendo, aqui, tanto a letra das canções, aquilo que hoje chamaríamos propriamente de "o poema", i.e., seu texto, quanto a estrutura da língua em sua articulação sonora. Por outro lado, poiésis, do verbo poiéō (lit. "fazer", "confeccionar", donde "poema", poíêma, lit. "artefato"), refere-se ao trabalho intricado com a palavra; melos e aōidé, referem-se à dimensão musical da palavra cantada: aquele é um termo cujo sentido mais esquemático é o de "membro, parte, peça" e, na acepção musical, refere-se, portanto, a uma peça musical completa, ou a uma divisão desta; este denota a própria palavra cantada, o imbricamento dos dois conceitos fica claro no substantivo composto melōidía , que indica tanto o que entendemos por "melodia", isto é o acompanhamento musical, quanto o canto em sua dimensão verbal. Finalmente, molpé refere-se à dança associada a uma canção e khoreía, à dança em geral, ou àquela executada por um grupo de dançarinos. Para uma discussão detalhada dos termos, cf. especialmente Pagliaro (1953) e Brose (2014). 
11. Porém, não gráficos.

12. Isto é, que se repetem a cada linha ou verso, que, em grego, se diz stíkhos. A situação é mais complicada para os metros líricos, que merecem um tratamento em separado.

13. Zumthor (2010). Compare com o prelúdio da $1^{\text {a }}$ ode pítica de Píndaro, em que uma concepção semelhante é expressa.

14. Maiakovski, How are verses to be made? in Gorky (2000), p. 145, "Rhythm is the basic force and the basic energy of poetry. It cannot be explained, it can only be described, like the effects of magnetism or electricity. Magnetism and electricity are forms of energy. The rhythm may be identical in many poems, even in everything the poet has written, but this doesn't make that work uniform, since rhythm can be so complex and difficult of formulation that the poet may totally fail to achieve it in a number of major works", grifo meu.

15. Arist. Quint. Perì Mousikês (Tratado sobre a Música), 1.14-18. Uma ótima tradução desses tratados musicais pode ser encontrada em Barker (2004), p. 402 et seq.

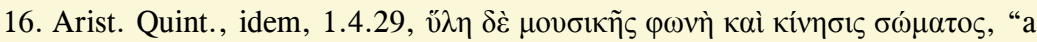
matéria da música é a voz e o movimento do corpo". Uma formulação semelhante é dada por Platão, nas Leis, 672e.

17. Sobre questões de equivalência na tradução dos metros gregos, $c f$. o excelente artigo de Tápia (2004).

18. Esses termos são explicados mais abaixo.

19. As exceções são raras, como deveriam, ademais: não se pode esperar que todos os filólogos sejam poetas e, ademais, o exercício da filologia, em sua malfadada tentativa de se impor como ciência, não raro contribui para um embotamento da sensibilidade poética e para uma elevação dos originais à categoria de textos sensíveis, sobre isso, $c f$., especialmente, Nida (1997). Não teríamos espaço para tratar dessas questões aqui. Pretendo retomá-las em um outro artigo. 
20. O cenário começa a mudar, e por duas razões principais: hoje sabemos muito mais sobre a música grega antiga a ponto de permitir reconstruções que, quando não são as melodias originais (um conceito, ademais, que tem a sua própria complexidade), são, ao menos, coerentes com a teoria musical antiga. Além disso, com evidências cada vez mais convincentes de que a melodia original provavelmente era de importância secundárias para as futuras reperformances de uma peça, muitos experimentalistas, numa atitude salutar, têm se dedicado a propor suas próprias reconstruções, embasadas ou não na teoria musical antiga. No campo teórico, são essenciais os trabalhos de Corrêa (2008), Hagel (2009) e West (1992). Entre os experimentalistas, o próprio Hagel, em colaboração com G. Danek, propôs uma reconstrução e uma técnica de canto homérico bastante eficaz, disponíveis na página da Österreichische Akademie der Wissenschaften. Eu chamaria a atenção para o excelente trabalho de Halaris, C., Ancient Greek Music (CD Audio). Atenas: Cultural Action - EMSE., 2008. 2 CD; de Tabouris, P., Music of Greek Antiquity. Atenas: Paián, $n^{\circ} 653$, 2012. 1 CD, e Tabouris, P., Secular Music of Greek Antiquity, 2 vols. Atenas: FM Records, $\mathrm{n}^{\circ} 808$ e 809; do Ensemble Kérylos, De la pierre au son: musiques de l'Antiquité grecque et romaine. Condutor, Annie Bélis. K617, 1996; do Ensemble Mélpomen, Melpomen: Ancient Greek Music. Condutor, C. Steinmann. Scholia Cantorum Baliensis Documenta. Basel: Harmonia Mundi, 2006. 1 CD; do De Organografia, Music of the Ancient Greeks. Pandourion Records, 1995-97, 1CD; do Atrium Musicae de Madrid, Musique de la Grèce Antique. Condutor, G. Paniagua. Harmonia Mundi, 2000. 1 CD.

21. Cf. Zumthor (2010), p. 39-40.

22. Schlegel (2010), p. 123, "Considero uma exigência bem justa, nas traduções, que a crítica deva vir acompanhada de uma sugestão construtiva".

23. West (1982), sendo uma exceção, até onde sei.

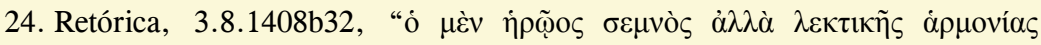

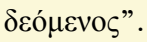

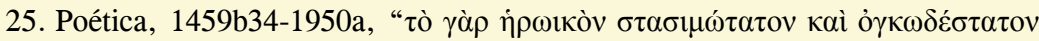

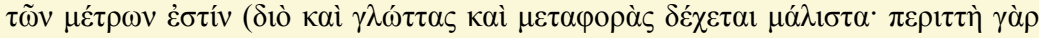

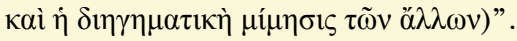


26. Interpretado por Heféstião como a forma catalética ou abreviada do dátilo. Sobre isso confira mais abaixo. O traço vertical sobre cada um dos pés indica a posição da tese, ou tempo marcado; a arse, ou tempo não-marcado, não é distinguida por nenhum sinal. $\mathrm{O}$ emprego dos termos tese e arse deve ser entendido em seu sentido antigo, que estava relacionado com a dança: a tese é o tempo de bater o pé no chão (downbeat) e, por isso mesmo, é a posição marcada do grupo rítmico; a arse, ao contrário, é o tempo de levantar o pé (upbeat) e, portanto, encontra-se na porção não marcada do mesmo grupo. No hexâmetro, a longa preenche toda a tese e as duas curtas, a arse.

27. Na nomenclatura utilizada para o posicionamento dos elementos métricos, $\mathrm{L}$ quer dizer "longa"; c, "curta". O primeiro número refere-se ao pé; o segundo, à posição dentro de cada pé. Dessa forma, L4 significa " a longa do quarto pé" e $\mathrm{c}_{42}$ significa "a segunda curta do quarto pé".

28. Fala-se então de "contração". Ao fenômeno oposto, ou seja, uma longa substituída por duas breves, dá-se o nome de "resolução".

29. A ideia, no entanto, de que o quinto pé nunca pode ser substituído por um espondeu é errônea e reflete falta de familiaridade com a dinâmica real do ritmo hexamétrico de qualquer período. Na verdade, este tipo de verso, conhecido como versus spondiacus, aparece em $3.8 \%$ de todo o corpus homérico e em 5,2\% do hesiódico, Sicking (1993), p. 30.

30. Para maiores detalhes, $c f$. Sicking (1993).

31. Korzeniewski (1968). Esse, aliás, é o número máximo de permutações possíveis: uma vez que a primeira posição de cada dátilo é sempre ocupada por uma longa e que o último pé também sempre apresenta uma longa (natural ou alongada) na segunda posição, as combinações possíveis para os cinco pés restantes $(\mathrm{CP}$, correspondente ao intervalo entre $\mathrm{C} 1-\mathrm{C} 5)$ é igual ao número de elementos possíveis na segunda posição de cada pé $\left(\mathrm{P}_{2}\right.$, que são dois: longo ou dois breves) elevado à potência do número de posições restantes (n). $\mathrm{CP}$, portanto, é igual a $\mathrm{P}_{2}{ }^{\mathrm{n}}=2^{5}=32$.

32. Essas, ademais, ao invés de seguirem a prosódia grega, são muitas vezes empregadas de acordo com os usos e costumes do vernáculo, apresentandose como um empecilho à correta pronúncia do verso. A intrusão de vírgulas desnecessárias aparece, sobretudo, em edições alemãs, que costumam separar a oração principal da subordinada por vírgula. 
33. A qual, por definição, é igual à soma dos intervalos de duas curtas.

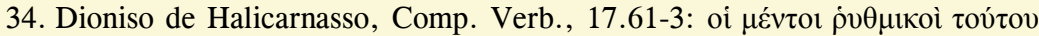

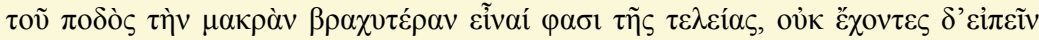

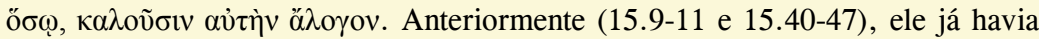
introduzido a noção de que duas longas (bem como duas breves) nem sempre têm a mesma duração, uma ideia que deve remeter a uma teoria musical mais elaborada, que ele, em seu tratado de retórica, infelizmente se escusa de detalhar.

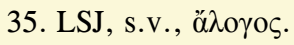

36. Por exemplo, Dionísio Halicarnasso, falando dos quatro valores temporais em que uma curta poderia ser subdividida, nos diz que (15.24-26) "Essas são, portanto, as quatro diferenças das sílabas curtas no que diz respeito à percepção não quantificável (álogon aísthesin) de sua alteração com relação ao metro. $\mathrm{O}$ mesmo raciocínio vale para a sílaba longa". Minha tradução de álogos por "não quantificável” (i.e., por meio de uma razão numérica e, daí, irracional) pretende evitar a ambiguidade com o termo "irracional" no sentido de "instintivo", já que aqui o termo retém o seu sentido técnico provavelmente derivado de Aristoxeno e Aristides Quintiliano, e.g., 1.14.33 et seq.

37. Porém mesmo nas formas cantadas ou líricas, em que o ritmo musical poderia, em princípio, impor-se sobre o prosódico, a resolução da tese em duas curtas é sistematicamente evitada. Exceções que, na verdade, confirmam a regra, são raras: Íbico, fr. 185.3; Eurípides, Andromâca, 490 (= 482); Baquílides, 140; Aristófanes, Assembléia de Mulheres, 1171. Um caso interessante, em que um dátilo com tese em duas breves responde, na estrofe seguinte, a outro com tese em longa é Eurípides, Fenícias, 796 e 813. Note que a frequência dessas resoluções em Eurípedes pode apontar, ademais, para inovações musicais que iriam se sedimentar nas décadas seguintes. Para uma excelente discussão do tema, cf. Gentili e Lomiento (2003).

38. Também chamado antidátilo, pelos metricistas antigos. $\mathrm{O}$ anapesto aparece apenas em sizígias, i.e., um metro composto por dois pés, ๒レ-்レ'.

39. O que, ademais, a torna uma longa "perfeita" para usar a nomenclatura de Dionísio.

40. Daí porque a melhor representação esquemática para o anapesto seria $\widetilde{\longleftarrow}$. 
41. Hefestião, Manual de Metros, 7.1-2; Aristides Quintiliano, op. cit., 1.24-25. A catalexe (do gr. katálēksis) é a supressão de uma ou mais partes de um pé ao final de um verso.

42. O sinal A após o pé indica catalexe. Colocado antes do pé, ele indica "acefalia", ou perda de uma mora no início do pé.

43. Cf. Parry (1929), que utiliza a denominação "necessário" para o acavalamento sintático e "periódico" para o que, não sendo complemento sintático do verso anterior, servia, no entanto, para expandir e dar continuidade à narrativa por parataxe.

44. Dentro ou fora de um pé: no primeiro caso, fala-se de cesura; no segundo, de diérese.

\section{Snell (1982).}

46. Seguindo a simbologia utilizada por Snell (1982), pontes são indicadas por $\backsim$; as posições em que fim-de-palavra são esperadas, por :.

47. Isto é, não pode haver fim-de-palavra no meio ou ao final do segundo pé. Essa limitação é conhecida como Lei de Meyer, mas aplica-se rigorosamente apenas aos poetas alexandrinos. Em Homero, segundo West (1982), há uma exceção à "lei" a cada 20-30 linhas.

48. Pentemímere, "que ocorre depois de cinco (penta) metades (hemímeros)", o mesmo vale para heptemímere (hepta, i.e., sete), "que ocorre depois da sétima metade", porque o dátilo é formado por duas metades, uma tese, onde está a longa, e uma arse, onde estão as duas curtas: - $\mid \cup \cup$. As denominações "masculina" ou "feminina" derivam do fato de que pode se dizer que a primeira parte do verso, se analisada em isolado, é formada por um metro chamado de "hemiepos" (literalmente, "meio epos", isto é, meio hexâmetro), ou seja, um verso da forma

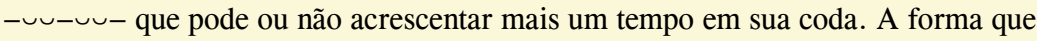
termina numa longa, como a citada, é chamada de "hemiepos masculino" e a que termina com uma curta a mais, $-\backsim \cup-\cup \cup-\cup$, é chamada "hemiepos feminino".

49. Assim chamada por ser comum nos poetas bucólicos, como Teócrito. 
50. Fränkel (1955), p. 100-156.

51. “Sense-pause”, para West (1982), usando a nomenclatura de Fränkel.

52. De acordo com West (1982), p. 36. No entanto, é preciso cautela com esses números, uma vez que o autor não cita suas fontes, nem explica como chegou a eles.

53. Kirk (1993), vol 1, p. 17 et seq.

54. Op. Cit.

55. Isto é, certamente em performance a elisão marcava uma emissão continua

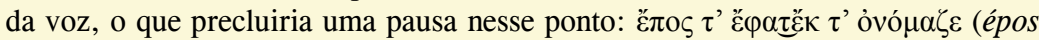
t'éphaték t'onómazde). O fato de a elisão dar-se, aqui, na arse em uma sílaba curta, a distingue de outras ocasiões em que temos uma elisão que não afeta a cesura, ou por dar-se na tese, e/ou por ocorrer em sílaba longa, como no exemplo $\mathrm{n}^{\mathrm{o}} 3$, abaixo.

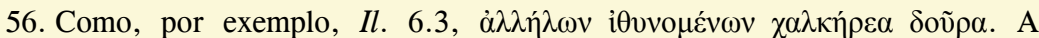
frequência desses versos sem cesura seria, de acordo com West (1982), 14\%o na Ilíada, 9\%o na Odisseia e 22\%o em Hesíodo.

57. Quanto à relação de tempos entre os cola, respectivamente 6:8:10.

58. Snell (1982), p. 14, já dizia que "Die verschiedenen Einschnitte und der Wechsel von 3- und 2silbigen Daktylen machen den Hexameter außerordentlich bildsam".

59. Meillet (1923).

60. Nagy (1990).

61. O segundo pé é uma variante hipercatalética, i.e., com uma sílaba a mais.

62. P. Oxy. 2735.17. 
63. Todo esse verso está no acusativo.

64. O que não implica, de maneira alguma, que Estesícoro use hexâmetros em seus poemas, uma vez que a longa está no lugar que poderia ser ocupada por uma única breve, havendo a possibilidade de gerar o padrão - --, nunca admitido no hexâmetro. As relações são válidas na diacronia apenas.

65. Por exemplo, Alceu, fr. 343.

66. Por exemplo, Safo, fr. 44.

67. Nagy (1990, p. 459), p. 459, "The phraseology that constitutes the repertoire of hexameter, I submit, comes from the rhythmical frame of not only the dactyloepitrite but also Aeolic meters", contudo, ele continua mais adiante (p. 460), "phraseological patterns generate metrical patterns that then assume dynamics of their own and even regulate any incoming nontraditional phraseology".

68. Usado, por exemplo, por Arquíloco em seus epodos.

69. Korzeniewski (1968, p. 33), p. 33, "Der durch die bukolische Dihärese wie eine Mikrostrophe gegliederte Hexameter - man könnte an daktylischen Tetrameter + versus Adoneus) denken - zeigt bisweilen an den beiden Koloenden eine Wortassonanz". Esse arranjo métrico, com idêntico fim-de-palavra entre o 4da e o ado é atestado de: Tebaida Estesícoro, fr. 222(b) PMGF, de forma fragmentária no $v .230$ (vide abaixo), que responde ao v. 209, onde não há fim-

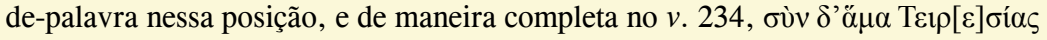

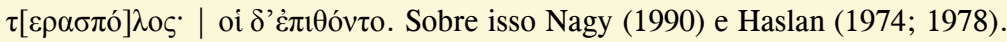

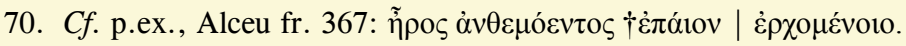

71. Outro exemplo é Safo, fr. 105V.

72. Os glicônios com expansão coriâmbica representariam um estágio anterior na evolução da fraseologia rítmica, tanto porque o ferecrácio é uma forma derivada do glicônio, tanto porque essa derivação tem a ver com as pausas impostas por fim-de-palavra, o que, em última análise poderia ter motivado a translação de esquemas do tipo gli + cor para glic + dat e, finalmente, fer + dat. Sobre isso, cf. Nagy (1990). 
73. Heféstião, Manual de Metros, 10.6, que classifica esse esquema entre os "ritmos contrastantes" ( $\dot{\alpha} v \tau \imath \sigma \pi \alpha \sigma \tau \iota \kappa o i ́)$.

74. O final do verso está faltando após o colchete, mas, pela análise da resposta métrica com as outras estrofes que temos, a coda só poderia assumir o formato mostrado.

75. Tentei preservar a figura etimológica do original, de capital importância para

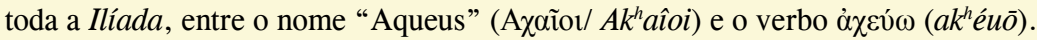
Sobre esse relacionamento, $c f$. Nagy (1979).

76. Isto é, os ventos Norte e Oeste, a que Aquiles reza para que soprem sobre a pira de Pátroclo, que até então se recusava a queimar.

77. Acerca desse tipo de análise que eu faço aqui, $c f$. Bakker (1997), sobretudo os capítulos 4 e 5 .

78. Ou "multifamoso" ou ambos, o significado do composto é ambíguo.

\section{Referências}

BAKKER, E. J. Poetry in Speech: Orality and Homeric Discourse. Ithaca/ London: Cornell University Press, 1997.

BARKER, A. Greek Musical Writings: Volume 2, Harmonic and Acoustic Theory. Cambridge: Cambridge University Press, 2004.

BAUMAN, R.; BRIGGS, C. L. Poetics and performance as critical perspectives on language and social life. Annu. Rev. Antropol., v. 19, p. 59-88, 1990. 
BROSE, R. D. Epikomios Hymnos: investigações sobre a performance dos epinícios pindáricos. 2014. Tese (Doutorado). FFLCH/DLCV, Universidade de São Paulo, São Paulo.

CORRÊA, P. D. C. Hamonia: mito e música na Grécia antiga. 2a ${ }^{\mathrm{a}}$. São Paulo: Humanitas, 2008.

EVANS, V. A Glossary of Cognitive Linguistics. Edinburgh: Edinburgh University Press, 2007.

FINNEGAN, R. Oral Traditions and the Verbal Arts: A Guide to Research Practices. Londres: Routledge, 1992:2003.

FRÄNKEL, H. Der homerische und der kallimachische Hexameter. In: (Ed.). Wege und Formen frühgriechischen Denkens, 1955. p.100-56.

GENTILI, B. Poetry and Its Public in Ancient Greece: From Homer to the Fifth Century. Tradução por A. Thomas Cole. Baltimore and London: Johns Hopkins University Press, 1990.

GENTILI, B.; LOMIENTO, L. Metrica e ritmica. Milão. 2003.

GORKY, M.; MAYAKOVSKY, V.; MILLER, A. On the Art and Craft of Writing. Traduzido por A. Miller. University Press of the Pacific, 2000.

HAGEL, S. Ancient Greek Music: A New Technical History. Cambridge: Cambridge University Press, 2009.

HASLAN, M. Stesichorean Metre. Quaderni Urbinati di Cultura Classica, v. 17, p. 7-57, 1974.

. The Versification of the New Stesichorus (P. Lille $76 \mathrm{abc}$ ). GRBS, v. 19, p. 29-57, 1978.

HAVELOCK, E. The Oral-literate equation: a formula for the modern mind. In: OLSON, D. R. e TORRANCE, N. (eds.). Literacy and Orality. Cambridge: Cambridge University Press, 1991. p.11-27. 
HAVELOCK, E. A. Prefácio a Platão. Traduzido por Enid Abreu Dobranzky. Campinas: Papirus, 1996.

KIRK, G. S. et al., (eds.) The Iliad: A Commentary. Cambridge: Cambridge University Press, v. 3, The Iliad: A Commentaryed. 1993.

KORZENIEWSKI, D. Griechische Metrik. Die Altertumswissenschaft. Darmstadt: Wissenschaftliche Buchgesellschaft 1968.

MEILlET, A. Les Origines Indo-européennes des Mètres Grecs. Paris: Les Presses Universitaires de France, 1923.

NAGY, G. The best of the Achaeans. Johns Hopkins University Press, 1979.

. Pindar's Homer. Baltimore: The Johns Hopkins University Press, 1990. Disponível em: < http://www.press.jhu.edu/books/nagy/PH.html >.

NIDA, E. A. Translating a text with a long and sensitive tradition. In: SIMMS, K. (Ed.). Translating Sensitive Texts: linguistic aspects. Rodopi, 1997. p. 333. (Approaches to Translation Studies).

PAGLiARO, A. Aedi e Rapsodi. In: (Ed.). Saggi di Critica Semantica. Messina, Florença, 1953. p.3-62.

SCHLEGEL, A. W. Über die Bhagavad-gita. Traduzido por Maria Aparecida Barbosa. In: HEIDERMANN, W. (Ed.). Clássicos da Teoria da Tradução: alemão-português. $2^{\text {a }}$ edição, revisada e ampliada. Florianópolis: UFSC/Núcleo de Pesquisa em Literatura e Tradução, v.1, 2010. p.120-127. (Clássicos da Teoria da Tradução).

SICKING, C. M. J. Griechische Verslehre. Munique: C.H. Beck'sche Verlagsbuchhandlung, 1993.

SNELL, B. Griechische Metrik. 4. Göttingen: Vanderhoeck \& Ruprecht, 1982.

TÁPIA, M. Questões de equivalência métrica em tradução de poesia antiga. Revista Letras, n. 89, p. 17, 2004. ISSN 0100-0888. 
THIONG'O, N. Penpoints, Gunpoints, and Dreams: Towards a Critical Theory of the Arts and the State in Africa. Oxford University Press, USA, 1998.

THOMAS, R. Oral Tradition and Written Record in Classical Athens. Cambridge: Cambridge University Press, 1989.

. Literacy and Orality in Ancient Greece. Cambridge Cambridge University Press, 1992.

WEST, M. L. Greek metre. Clarendon Press, 1982.

. Ancient Greek Music. Oxford: Oxford University Press, 1992.

ZUMTHOR, P. Introdução à Poesia Oral. Traduzido por Jerusa Pires Ferreira, Maria Lúcia Diniz Pochat e Maria Inês de Almeida. Belo Horizonte: UFMG, 2010. ISBN 9788570417596.

Recebido em: 15/08/2015 Aceito em: 01/10/2015 